\title{
Temperament and major depressive disorder
}

\author{
Elie G Karam ${ }^{1,2,3^{*}}$, Mariana M Salamoun ${ }^{3}$, Joumana S Yeretzian ${ }^{3}$, Zeina Mneimneh ${ }^{3,4}$, Aimee N Karam², ${ }^{1,2,}$ \\ John Fayyad ${ }^{1,2,3}$ \\ From $1^{\text {st }}$ International Congress on Neurobiology and Clinical Psychopharmacology and European \\ Psychiatric Association Conference on Treatment Guidance \\ Thessaloniki, Greece. 19-22 November 2009
}

The Lebanese-Arabic TEMPS-A (Temperament Evaluation of the Memphis, Pisa, Paris and San Diego Autoquestionnaire) was used to assess the association between affective temperament and mental disorders in a nationally representative sample of the Lebanese Evaluation of the Burden of Ailments and Needs Of the Nation study(L.E.B.A.N.O.N). The five affective temperaments were associated with mental disorders with anxious temperament having a risk role while hyperthymic temperament having a protective role. This presentation will focus on the specific association between temperament and the age of onset of major depressive disorder.

\section{Author details}

${ }^{1}$ Department of Psychiatry and Clinical Psychology, St George Hospital University Medical Center, Beirut, Lebanon. ${ }^{2}$ Department of Psychiatry and Clinical Psychology, Balamand University Medical School, Beirut, Lebanon. ${ }^{3}$ Institute for Development Research Advocacy, and Applied Care (IDRAAC), Beirut, Lebanon. ${ }^{4}$ Program in Survey Methodology, Institute for Social Research, University of Michigan, USA.

Published: 22 April 2010

Submit your next manuscript to BioMed Central and take full advantage of:

- Convenient online submission

- Thorough peer review

- No space constraints or color figure charges

- Immediate publication on acceptance

- Inclusion in PubMed, CAS, Scopus and Google Scholar

- Research which is freely available for redistribution 